\title{
GENETIC DIVERSITY OF TEAK (Tectona grandis L.F.) FROM DIFFERENT PROVENANCES USING MICROSATELLITE MARKERS ${ }^{1}$
}

\author{
Berenice Kussumoto Alcântara² e Elizabeth Ann Veasey²
}

\begin{abstract}
Teak (Tectona grandis) is one of the main timber species in the world with high economic value, famous for its beauty, strength and durability. The objective of this work was to characterize the genetic diversity of teak genotypes used in Brazilian plantations. Nine microsatellite primers were used to assess 60 teak genotypes, including 33 genotypes from seeds of plantations and 14 clones from Cáceres municipality, Mato Grosso State, Brazil, and 13 clones from Honduras, Malaysia, India, Indonesia, Ivory Coast and Solomon Islands. Two groups of genotypes were detected using the Bayesian Structure analysis: 80\% were placed in group 1, represented by genotypes from Cáceres and one from Malaysia, and 20\% allocated in group 2, composed of clones from India, Solomon Islands, Malaysia and Honduras and the clones from the Ivory Coast. Most of the genetic variability (73\%) was concentrated within groups according to AMOVA analysis. Genetic parameters were estimated for the two groups obtained in the analysis of Structure. Moderate genetic diversity was found, with 4.1 alleles per locus, on average, and an average heterozygosity of 0.329 , which was lower than the expected heterozygosity $\left(H_{e}=0.492\right)$. Group 1 showed the lowest values for these parameters. Suggestions were made concerning the identification of contrasting genotypes to be used as parents in breeding programs.
\end{abstract}

Keywords: Genetic characterization; Germplasm; Molecular markers.

\section{DIVERSIDADE GENÉTICA DE TECA (Tectona grandis L.F.) DE DIFERENTES PROCEDÊNCIAS USANDO MARCADORES MICROSSATÉLITES}

\begin{abstract}
RESUMO - A teca (Tectona grandis) é uma das principais espécies de madeira do mundo, com alto valor econômico, famosa por sua beleza, resistência e durabilidade. Este estudo teve como objetivo caracterizar a diversidade genética de genótipos de teca usados em plantios brasileiros. Foram utilizados nove primers microssatélites para avaliar 60 genótipos de teca, incluindo 33 genótipos de sementes de plantações e 14 clones de Cáceres, Município de Mato Grosso, Brasil, e 13 clones oriundos de Honduras, Malásia, Índia, Indonésia, Costa do Marfim e Ilhas Salomão. Dois grupos genotípicos foram detectados por meio da análise Bayesiana: $80 \%$ dos genótipos foram alocados no grupo 1, representado por materiais de Cáceres e um da Malásia; e 20\% alocados no grupo 2, sendo este composto por clones da Índia, Ilhas Salomão, Malásia e Honduras e clones da Costa do Marfim. De acordo com a análise de variância (AMOVA), a maior parte da variabilidade genética (73\%) está concentrada dentro de grupos. Os parâmetros genéticos foram estimados para os dois grupos obtidos na análise do Structure. Foi detectada diversidade genética moderada, com 4,1 alelos por loco, em média, e heterozigosidade média observada de 0,329, sendo menor que a esperada $\left(H_{e}=0,492\right)$. O grupo 1 apresentou os menores valores para esses parâmetros. Sugestões foram feitas com relação à identificação de genótipos contrastantes para serem utilizados como parentais em programas de melhoramento.
\end{abstract}

Palavras-chave: Caracterização genética; Germoplasma; Marcadores moleculares.

\footnotetext{
${ }^{1}$ Recebido em 22.10.2012 aceito para publicação em 06.08.2013.

${ }^{2}$ Universidade de São Paulo, Escola Superior de Agricultura Luiz de Queiroz, USP, Brasil. E-mail: <bereniceka@gmail.com> e<eaveasey@usp.br>.
} 


\section{INTRODUCTION}

Teak (Tectona grandis L.f.) is a diploid tree species with $2 n=36$ chromosomes (HEDEGART; EIGAARD, 1965), classified in the Lamiaceae family according with APG III (ANGIOSPERM PHYLOGENY GROUP, 2009). The species occurs naturally in Southeast Asian countries, especially India, Myanmar, Thailand and Laos with discontinuous distribution between $10^{\circ}$ and $25^{\circ} \mathrm{N}$ and between $0^{\circ}$ and $10^{\circ} \mathrm{S}$, at sea level to $1300 \mathrm{~m}$ altitude (GRAUDAL et al., 1999; VERHAGEN et al., 2010). Teak was introduced in many countries of Asia and some of Africa and America. Verhagen et al. (2010) suggested that a possible origin of African plantations came from North India. In Brazil, the commercial plantations of teak began in the late 60's in the city of Cáceres, Mato Grosso State. However, the natural origin of Brazilian plantations is not known with certainty, although many of their provenances are known to come from Trinidad Island (ALCÂNTARA, 2009). The success of teak plantation in Brazil occurs due to climatic conditions that are similar to the countries of the species origin (MATRICARDI, 1989). In addition to the favorable climatic conditions and soil fertility, the most appropriate and intensive silviculture management practices helped to reduce the production cycle from $60-80$ years in the region of teak's origin (UGALDE; PÉREZ, 2001) to only 25 years in Cáceres (TSUKAMOTO FILHO, 2003).

Currently, Brazil possess around 65,000 ha of planted teak area in which Mato Grosso State has the largest area (FAO, 2012). However, teak reforestation has been extended towards the states of Acre, Pará and Rondônia, replacing the native raw material originated from irrational explorations of Amazon forest (FIGUEIREDO, 2001). Some native species under planting conditions are not satisfactory, because many of them suffer from severe attacks of pests and diseases. For example, in reforestation with mahogany (Swietenia macrophylla King.) strongly attacked by the borer Hypsipyla grandella (Lepidoptera: Pyralidae) that destroys the apical meristem, promoting an irregular growth of the trunk and impending commercial exploitation (NEWTON et al., 1994). Furthermore, exotic species in Brazil, such as teak, have adapted very well, probably because of its pest tolerance and rusticity (FIGUEIREDO, 2001). In addition, teak plantations are usually deployed in areas of former pasture.
Besides the environmental importance of teak in Brazil with respect to an aid in mitigating the exploitation of native species in the Amazon, it also has economic importance where the FOB price of a cubic meter of wood can reach around US\$ 4,111 (KOLLERT and CHERUBINI, 2012). However, the price can vary according to log diameter and wood quality (TSUKAMOTO FILHO, 2003). Worldwide, teak plantations represent $4 \%$ of the total area of planted forests (KRISHNAPILLAY, 2000), mainly due to the quality of its wood for the production of noble purposes and fine furniture, to be used in carpentry and shipbuilding industry, where it is almost irreplaceable, as it resists sun, heat, cold, rain and the sea (RONDON NETO, 1998). The main producers of teakwood are Myanmar, India and Indonesia and the principal importers are China, EUcountries and the United States (KOLLERT; CHERUBINI, 2012).

Thus, tying its high economic value with its qualities of strength and durability, teak has a great potential to be a substitute in the market for mahogany. Therefore, the decrease in the supply of tropical timber found in natural areas and environmental awareness of consumers, are decisive factors for the increase of teakwood demand. However, studies that could help breeding programs of teak, such as genetic diversity studies, are scarce in Brazil. They are concentrated on countries where the crop has greater economic significance (KERTADIKARA; PRAT, 1995; KJAER et al., 1996; GANGOPADHYAY et al., 2003; WATANABE; WIDYATMOKO, 2004; SHRESTHA et al., 2005; FOFANA et al., 2009).

The species reproduces mainly by cross-fertilization. Kjaer et al. (1996) found values between 89\% and 95\% for the outcrossing rate in different teak populations. Changtragoon et al. (2000) observed similar outcrossing rates (82\% to 97\%) in teak populations from Thailand using RAPD (Random Amplified Polymorphic DNA). Therefore, the reproductive system by outcrossing observed in teak enables high levels of genetic diversity within teak populations, considering that outcrossing favors recombination (HARTL, 2008).

Genetic diversity studies in teak were conducted by Shrestha et al. (2005) who studied 28 genotypes of teak from India, Indonesia and Thailand using AFLP (Amplified Fragment Length Polymorphism) and found that $57 \%$ of the variance occurred within populations, while $43 \%$ occurred among populations. Both principal 
coordinate and cluster analysis indicated that the populations from India are quite separate from those of Thailand and Indonesia. However, the populations from the east coast of India were an exception, showing associations with both groups.

Microsatellites or SSR (Simple Sequence Repeats) markers were employed by Fofana et al. (2009), using 15 primers developed by Verhaegen et al. (2005) to evaluate 166 teak trees distributed in natural habitats of the species, in order to assist in conservation strategies. The study concluded that India is the main center of diversity of teak, which was consistent with previous studies using other markers. Populations of Thailand and Laos had half of the intra-population variability when compared to India, though they were genetically distinct from the Indian population.

In view of the importance of teak in Brazil and worldwide, this study aimed at characterizing the genetic diversity of 33 individuals originated from seeds planted in Cáceres, Mato Grosso, Brazil, and 27 clones of different origins, using microsatellite markers, and the relationship among these genotypes, including the detection of possible divergent parents to be used in a plant breeding program.

\section{MATERIALS AND METHODS}

\subsection{Teak genotypes}

The 60 teak genotypes assessed in this study were provided by two private companies: PROTECA, that provided 27 clones from different origins (14 clones obtained in Cáceres and 13 clones originated from Honduras, Malaysia, India, Indonesia, Ivory Coast and Solomon Islands); and FLORESTECA, that provided 33 individuals from Cáceres plantations originated from seeds. The genotypes were divided into eight groups according to their origin: 1 - individuals from seeds planted in Cáceres, with 33 genotypes; 2 - a clone from Solomon Islands, with one genotype; 3 - clones of superior genotypes from Cáceres, with 14 genotypes; 4 - clones from Malaysia, with two genotypes; 5 clones from India, with six genotypes; 6 - a clone from Indonesia, with one genotype; 7 - clones from Ivory Coast, with two genotypes; and 8 - a clone from Honduras, with one genotype (Table 1).

\subsection{DNA extraction and microsatellite analysis}

For DNA extraction, young leaves of each genotype were dehydrated for seven days using silica. DNA extraction was obtained from dehydrated leaves and then using the protocol based on CTAB extraction buffer described by Borges et al. (2009), with modifications. After extraction, DNA was quantified in $1 \%(\mathrm{p} / \mathrm{v})$ agarose gels using $3 \mu \mathrm{l}$ of DNA solution mixed with $1 \mu \mathrm{l}$ of Blue-green and $4 \mu \mathrm{l}$ of bromophenol blue (0.1\%). The running buffer used was TBE (1X), and the running time was 40 minutes at $110 \mathrm{~V}$. Gels were viewed with UV (BioGlow, model ZT-21) by the intensity of fluorescence emitted by the blue-green and photographed with a digital camera. This intensity was compared to standard DNA (lambda) with a range variation of 10, 20, 50, 80 and 100 ng. Quantified DNA was diluted in Milli-Q water to $5 \mathrm{ng} / \mu \mathrm{l}$.

For the amplification of genomic DNA, 10 primers established for $T$. grandis (VERHAEGEN et al., 2005) were used, but only nine were polymorphic (Table 2). One locus (CIRAD1TeakG02) was monomorphic and, therefore, excluded from the statistical analysis. A locus was considered polymorphic when the most common allele had a frequency less than 0.95 . The amplification by PCR was conducted in a final volume of $10.2 \mu \mathrm{l}$, ontaining: 15 ng template DNA, 1 U Taq-polymerase, $1.0 \mu \mathrm{l} 10 \mathrm{X}$ buffer, $\mathrm{MgCl}_{2}$ at $1.5 \mathrm{mM}$, primer $\mathrm{F}$ at $0.25 \mu \mathrm{M}$, primer R at $0.25 \mu \mathrm{M}$, each dNTP at $0.25 \mathrm{mM}$ and $3 \mu \mathrm{l}$ Milli-Q water. PCR amplifications were performed initially in gradient to test the best annealing temperature in a BioRad thermocycler, model MyCycler, with the following amplification conditions: denaturation at $94{ }^{\circ} \mathrm{C}$ for $4 \mathrm{~min}$, followed by 30 cycles at $94{ }^{\circ} \mathrm{C}$ for $30 \mathrm{~s}, 51^{\circ} \mathrm{C}$ and further annealing temperatures tested $\left(52{ }^{\circ} \mathrm{C}, 53^{\circ} \mathrm{C}, 55^{\circ} \mathrm{C}, 58^{\circ} \mathrm{C}, 60^{\circ} \mathrm{C}, 61^{\circ} \mathrm{C}\right.$ and $62^{\circ} \mathrm{C}$ ) for $45 \mathrm{~s}$ and $72^{\circ} \mathrm{C}$ for $45 \mathrm{~s}$, with a final extension at $72^{\circ} \mathrm{C}$ for $5 \mathrm{~min}$ (VERHAEGEN et al., 2005). Subsequently, DNA amplification for the genetic analysis was conducted under the same amplification conditions previously mentioned, but using, for each primer, the optimum annealing temperature.

The amplification products were subjected to electrophoresis on $6 \%$ non-denaturing polyacrylamide gels. The microsatellites bands on the gel were fixed with $0.2 \%$ silver nitrate dissolved in fixing solution ( $10 \%$ ethanol alcohol and $0.5 \%$ of acetic acid diluted in deionized water) for 5 minutes and the revelation was made using $0.32 \%$ of formaldehyde diluted in sodium hydroxide solution (3\%) (BASSAM et al., 1991). After processing, the gels were photographed with a digital camera. To assess the size of the bands we used ladders 
Table 1 - Groups of teak (Tectona grandis) genotypes used for genetic characterization.

Tabela 1 - Grupos de genótipos de teca (Tectona grandis) usados para a caracterização genética.

\begin{tabular}{|c|c|c|c|}
\hline $\begin{array}{l}\text { Provenance } \\
\text { identification }\end{array}$ & $\begin{array}{c}\text { Genotype } \\
\text { identification }\end{array}$ & Code & Provenance name \\
\hline 1 & 1 to 33 & $\mathrm{~S} 1$ to $\mathrm{S} 33$ & Individuals originated from seeds planted in Cáceres \\
\hline 2 & 34 & A3 & Clone from Solomon Islands \\
\hline \multirow[t]{14}{*}{3} & 35 & B1 & Clone from superior genotypes in Cáceres \\
\hline & 36 & B2 & “ \\
\hline & 37 & B3 & “ \\
\hline & 38 & B5 & “ \\
\hline & 39 & B6 & “ \\
\hline & 40 & B7 & “ \\
\hline & 41 & B8 & “ \\
\hline & 42 & B9 & “ \\
\hline & 43 & B11 & “ \\
\hline & 44 & B12 & “ \\
\hline & 45 & B13 & “ \\
\hline & 46 & B14 & “ \\
\hline & 47 & B16 & “ \\
\hline & 48 & B17 & “ \\
\hline \multirow[t]{2}{*}{4} & 49 & C1 & Clone from Perlis, Malaysia \\
\hline & 50 & $\mathrm{C} 2$ & Clone from Kota Marudu, Malaysia \\
\hline \multirow[t]{6}{*}{5} & 51 & D1 & Clone from northwest India \\
\hline & 52 & $\mathrm{D} 2$ & Clone from India, unknown region \\
\hline & 53 & D3 & Clone from east India \\
\hline & 54 & D4 & Clone from northeast India \\
\hline & 55 & D5 & Clone from India, unknown region \\
\hline & 56 & D6 & Clone from center west India \\
\hline 6 & 57 & E2 & Clone from Indonesia \\
\hline \multirow[t]{2}{*}{7} & 58 & G1 & Clone from Ivory Coast \\
\hline & 59 & G2 & “ \\
\hline 8 & 60 & $\mathrm{H} 1$ & Clone from Honduras \\
\hline
\end{tabular}

of $10 \mathrm{bp}$ and $100 \mathrm{bp}$ ( $40 \mathrm{ng} / \mathrm{mL}$ ) as standards. The resulting microsatellite bands were evaluated in a transluminator immediately after the end of revelation.

\subsection{Statistical analysis}

For the discrimination between the genotypes sampled, we used the Bayesian method using the STRUCTURE software, version 2.1 (PRITCHARD et al., 2000), to define the most probable number of groups (K). We used no admixture model and independent allele frequencies, using burn-in of 200,000 followed by an extension (run length) of 500,000. We carried out five independent interactions with $\mathrm{K}$ values ranging from 1 to 8 , while the optimal number of groups $(\mathrm{K})$ was estimated by the method proposed by Evanno et al. (2005). From the best value of K, the graph corresponding to this value was selected, considering the lesser variance among the five independent interactions performed. The separation of groups using the non-hierarchical graph from STRUCTURE was implemented with the coefficient of participation of the individual (Q) (PRITCHARD et al., 2000). A molecular variance analysis (AMOVA) was performed to determine the diversity within and between the groups formed in the STRUCTURE analysis, using the software Arlequin (EXCOFFIER et al., 2006).

Considering the two groups of teak genotypes obtained in the Structure analysis, the following genetic diversity parameters were estimated for each group and for each loci: number of alleles per locus $(A)$, observed heterozygosity $\left(H_{o}\right)$, expected heterozygosity or gene

Revista Árvore, Viçosa-MG, v.37, n.4, p.747-758, 2013 
diversity $\left(H_{e}\right)$, and fixation index $(F)$, using the GDA software (LEWIS; ZAYKIN, 2001). Allele frequencies and genetic diversity parameters of Nei (1973), such as total genetic diversity $\left(H_{T}\right)$, genetic diversity between groups $\left(D_{S T}\right)$, the proportion of genetic diversity between groups of genotypes $\left(G_{S T},\right)$ and genetic diversity within groups $\left(H_{S}\right)$ were estimated using FSTAT software (GOUDET, 1995). The Polymorphism Information Content (PIC) value was calculated according to Nei's statistic (Nei, 1973), where $P I C=1-\sum p_{i}^{2}$, and $\mathrm{p}_{\mathrm{i}}$ is the allele frequency, using co-dominant scores, of the $\mathrm{i}^{\text {th }}$ allele of a certain microsatellite locus detected in the germplasm.

Genotype associations were analyzed with DARwin v. 5.0 software (PERRIER et al., 2003). First, a modified Rogers genetic distance matrix (WRIGHT, 1978) was obtained with the TFPGA (MILLER, 1997) software. The diagonal matrix was then submitted to cluster analysis using the Neighbor-Joining algorithm and a dendrogram was built using the software DARwin v.5.0 (PERRIER et al., 2003) to determine the relationship among genotypes.

\section{RESULTS}

Although ten primers were used for the assessment of 60 teak genotypes, nine polymorphic loci were used for the statistical analysis, due to the fact that locus CIRAD1TeakG02 was monomorphic. Regarding the number of alleles per locus, locus 2 (CIRAD1TeakH10) had the highest value (7.0), and locus 5 (CIRAD3TeakDa09) showed the lowest (3.0). The average number of alleles per locus was 5.0 (Table 2).

The expected heterozygosity $\left(H_{e}\right)$ ranged from 0.298 for locus 1 (CIRAD1TeakF05) to 0.751 for locus 2 (CIRAD1TeakH10), with an average of 0.460 (Table 2). The observed heterozygosity $\left(H_{o}\right), 0.276$ on average, was lower than $H_{e}$, ranging from 0.10 for loci 5 (CIRAD1TeakDa09) and 7 (CIRAD4TeakDa12) to 0.5 for locus 2 (CIRAD1TeakH10). The PIC values ranged from 0.387 (locus 5) to 0.730 (locus 2), with an average of 0.490 . Loci with PIC values over 0.5 are considered very informative, while values between 0.25 and 0.5 are considered mildly informative and values below 0.25, uninformative (Botstein et al., 1980). Therefore, loci 2 (CIRAD1TeakH10), 4 (CIRAD2TeakC03) and 8 (CIRAD4TeakF02) were seen as very informative (with PIC values equal to $0.730,0.612$ and 0.546 , respectively), while the other six polymorphic loci in this study were considered mildly informative, according to the classification of Botstein et al. (1980).

For the analysis of diversity without hierarchy using the Bayesian approach performed by the software STRUCTURE, we tested values of $\mathrm{K}$ ranging from 1 to 8 where the optimal number of $\mathrm{K}$ was chosen from the values of $\Delta \mathrm{K}$ (EVANNO et al., 2005). By this methodology, $\mathrm{K}=2$ was found to be the optimal $\mathrm{K}$ value. The non-hierarchical graph was chosen in accordance with the assignment test considering $\mathrm{K}$ $=2$ (Figure 1 ). We observed that $80 \%$ of teak genotypes analyzed were placed in group 1 (gray color), with Q $\geq 0.5$ ( $Q$ = coefficient of individual participation). This group is represented by genotypes from Cáceres and one clone from Malaysia (C2). Considering $\mathrm{Q}<0.5$, $20 \%$ of the genotypes were placed in group 2 (white color), represented by genotypes A3 (Solomon Islands), C1 (Malaysia), D1, D2, D3, D4, D5 and D6 (India), E2 (Indonesia), H1 (Honduras) and G1 and G2 (Ivory Coast). The AMOVA for the two groups found in this analysis showed that the diversity within groups $(73 \%, \mathrm{P}<0.001)$ was greater than the diversity between groups (27\%, $\mathrm{P}<0.001$ ). The AMOVA result confirms Nei's genetic parameters (Nei 1973) where from a total diversity of 0.605 , most of this diversity was concentrated within groups $\left(H_{S}=0.495\right)$, when compared to proportion of the diversity among groups $\left(G_{S T}=0.182\right)$.

The number of alleles per locus was 3.8 for group 1 and 4.3 alleles for group 2, with 4.1 alleles per locus on average (Table 3). Higher values for the heterozygosity indices were also found for group 2 ( $\bar{H}_{o}=0.409 ; \bar{H}_{e}=0.617$ ) when compared to group 1 $\left(\bar{H}_{o}^{o}=0.248 ; \bar{H}_{e}=0.367\right)$. Considering both groups together, higher values were found for expected heterozygosity $\left(\bar{H}_{e}=0.492\right)$ compared to the average observed heterozygosity $\left(\bar{H}_{o}=0.329\right)$.

In the cluster obtained using the Neighbor-Joining algorithm, the genotypes were grouped coherently according to the Bayesian analysis, forming two groups (Figure 2). One group contained all the individuals from seeds, a few clones from Cáceres, together with the C2 clone from Malaysia; the second group contained a sub-group with all the clones from Cáceres and two individuals from seeds from Cáceres, and the D6 clone from India. Another sub-group contained the other accessions with different origins. It is interesting to

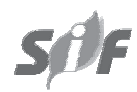

Revista Árvore, Viçosa-MG, v.37, n.4, p.747-758, 2013 
Table 2 - Sequences (F: forward, R: reverse) of nine microsatellite loci examined in teak (Tectona grandis) showing band size ranges, number of alleles per locus $(A)$, expected $\left(H_{e}\right)$ and observed heterozygosity $\left(H_{o}\right)$, and polymorphism information content (PIC).

Tabela 2 - Sequências (F: forward, R: reverse) de nove locos microssatélites examinados em teca (Tectona grandis), mostrando amplitude das bandas, número de alelos por loco $(\mathrm{A})$, heterozigosidade esperada $\left(\mathrm{H}_{e}\right)$ e observada $\left(\mathrm{H}_{0}\right)$ e conteúdo de informação de polimorfismo (PIC).

\begin{tabular}{|c|c|c|c|c|c|c|}
\hline Locus & 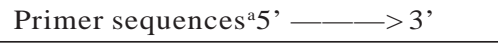 & Size range(bp) & A & $H_{e}$ & $H_{o}$ & PIC \\
\hline 1. CIRAD1TeakF05 & $\begin{array}{l}\text { F: CTTCTGCAACССТTTTTCAC } \\
\text { R: AGCCATATCTTCСTTTCTCT }\end{array}$ & $249-279$ & 5.0 & 0.298 & 0.267 & 0.394 \\
\hline 2. CIRAD1TeakH10 & $\begin{array}{l}\text { F: CGATACCTGCGATGCGAAGC } \\
\text { R: CGTTGAATACCCGATGGAGA }\end{array}$ & $225-273$ & 7.0 & 0.751 & 0.500 & 0.730 \\
\hline 3. CIRAD2TeakB07 & $\begin{array}{l}\text { F: GGGTGCTGATGATTTTGAGTT } \\
\text { R: CTAAGGAGTGAGTGGAGTTTT }\end{array}$ & $129-157$ & 6.0 & 0.328 & 0.200 & 0.406 \\
\hline 4. CIRAD2TeakC03 & $\begin{array}{l}\text { F: AGGTGGGATGTGGTTAGAAGC } \\
\text { R: AAATGGTCATCAGTGTCAGAA }\end{array}$ & $269-313$ & 5.0 & 0.632 & 0.350 & 0.612 \\
\hline 5. CIRAD3TeakDa09 & $\begin{array}{l}\text { F: CTCGCTTCTTTCCACATT } \\
\text { R: ATCATCGCGCATCGTCAA }\end{array}$ & $198-222$ & 3.0 & 0.326 & 0.100 & 0.387 \\
\hline 6. CIRAD3TeakF01 & $\begin{array}{l}\text { F: GCTCTCCACCAACCTAAACAA } \\
\text { R: AAAACGTCTCACСТTCTCACT }\end{array}$ & $198-234$ & 5.0 & 0.425 & 0.367 & 0.460 \\
\hline 7. CIRAD4TeakDa12 & $\begin{array}{l}\text { F: CGCACACCAGTAGCAGTAGCC } \\
\text { R: CCGGAAAAAGAAAAACCAAA }\end{array}$ & $129-171$ & 6.0 & 0.374 & 0.100 & 0.410 \\
\hline 8. CIRAD4TeakF02 & $\begin{array}{l}\text { F: CCGGTAAAAAGGTGTGTCA } \\
\text { R: GAGTGGAAGTGCTAATGGA }\end{array}$ & $217-243$ & 4.0 & 0.575 & 0.300 & 0.546 \\
\hline 9.CIRAD4TeakH09 & $\begin{array}{l}\text { F: GCAAACCAACCTTACT } \\
\text { R: CCGTTAGCACTCCATT }\end{array}$ & $149-175$ & 4.0 & 0.432 & 0.300 & 0.469 \\
\hline Average & - & - & 5.0 & 0.460 & 0.276 & 0.490 \\
\hline
\end{tabular}

${ }^{\text {a }}$ Primers developed by VERHAEGEN et al., 2005.
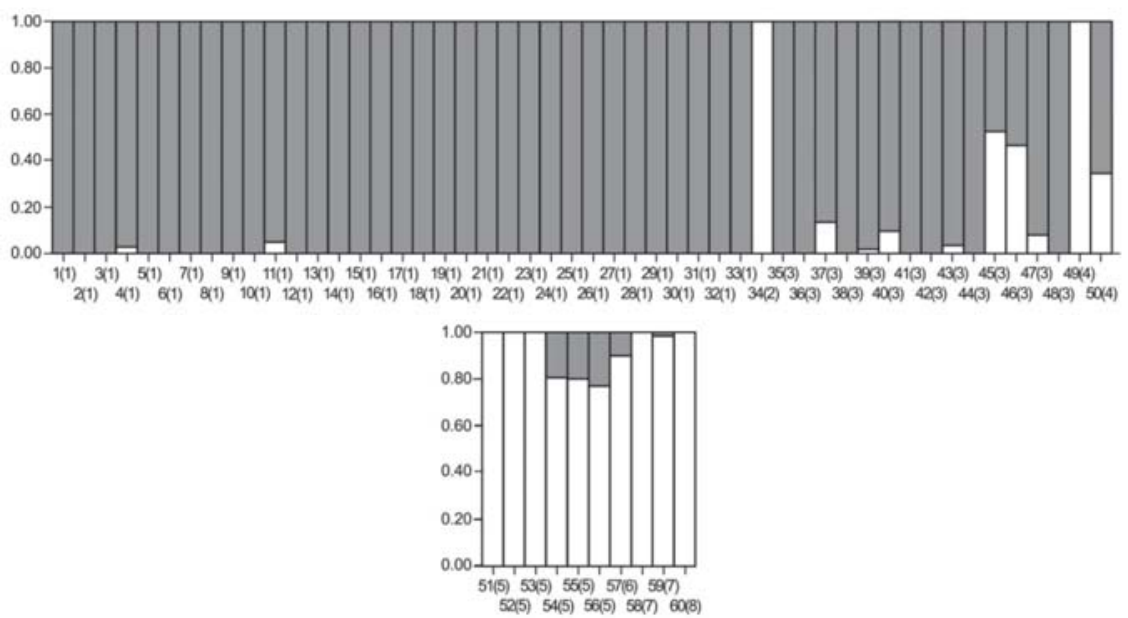

Figure 1 - Test allocation for the teak genotypes evaluated $(K=2)$. The identification of the genotypes are the numbers outside the parentheses (Table 1). Group 1 (gray color) is represented by genotypes from Cáceres and one clone from Malaysia (C2), while group 2 (white color) is represented by genotypes A3 (Solomon Islands), C1 (Malaysia), D1, D2, D3, D4, D5 and D6 (India), E2 (Indonesia), H1 (Honduras) and clones G1 and G2 (Ivory Coast). The $\mathrm{y}$ axes is represented by $\mathrm{Q}$ values = coefficient of individual participation in each group.

Figura 1 - Teste de alocação para os genótipos de teca avaliados $(K=2)$. Os genótipos estão identificados pelos números fora dos parênteses (Tabela 1). O grupo 1 (cor cinza) está representado por genótipos de Cáceres e um clone da Malásia (C2), enquanto o grupo 2 (cor branca) está representado pelos genótipos A3 (Ilhas Salomão), C1 (Malásia), D1, D2, D3, D4, D5 e D6 (Índia), E2 (Indonésia), H1 (Honduras), G1 e G2 (Costa do Marfim). O eixo y representa o valor de $Q$ = coeficiente individual de participação de cada grupo.

Revista Árvore, Viçosa-MG, v.37, n.4, p.747-758, 2013 
notice that the clones from Cáceres (green color) are mostly at an intermediate position between the individuals from seeds from Cáceres (red color) and all the other accessions. Also, the $\mathrm{H} 1$ clone, from Honduras, was the most divergent one within the second group.

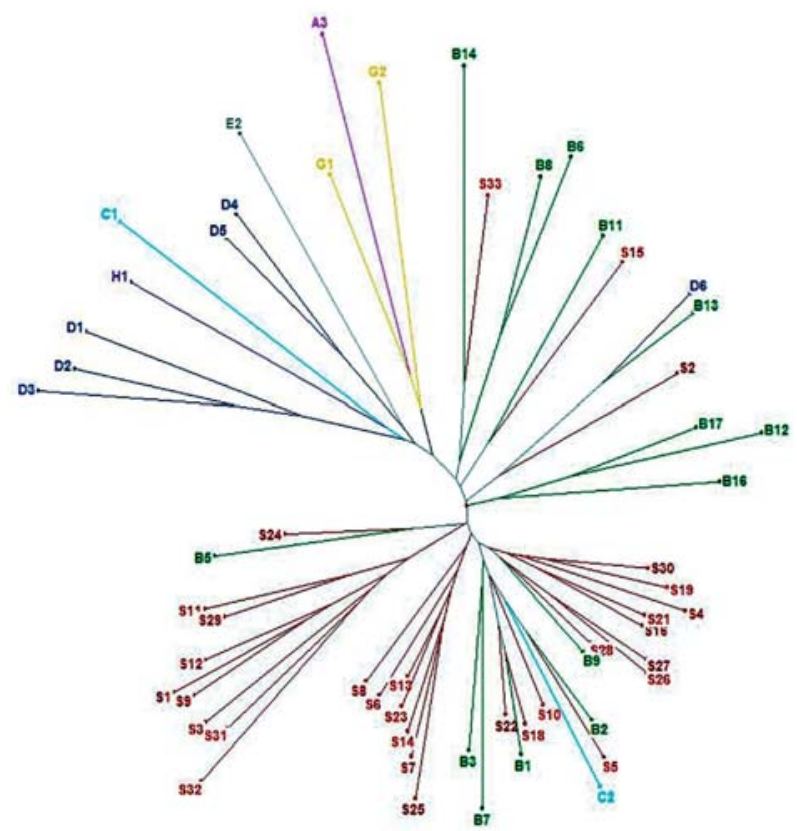

Figure 2 - Dendrogram using the Neighbor-Joining algorithm and Rogers distance modified by Wright (1978), showing the relationship of 60 genotypes of Tectona grandis and the formation of two groups as seen in the Bayesian analysis. Group I - genotypes from Caceres (S, red and B, green), a clone from Malaysia (C2, light blue); group II - a few genotypes from Caceres (S, red and B, green) closer to one genotype from India (D6, blue), and clones from India (D1, D2, D3, D4 and D5, blue), Indonesia (E2, gray), Malaysia (C1, light blue), Solomon Islands (A3, purple), Ivory Coast (G1 and G2, orange) and Honduras (H1, violet).

Figura 2 - Dendrograma usando algoritmo de NeighborJoining e a distância de Rogers modificada por Wright (1978), mostrando a relação dos 60 genótipos de Tectona grandis e formação de dois grupos, como visto na análise bayesiana. Grupo I-genótipos de Cáceres ( $S$, vermelho e B, verde) e um clone da Malásia (C2, azul claro); Grupo II - poucos genótipos de Cáceres ( $S$, vermelho e $B$, verde) próximos a um genótipo da Índia (D6, azul)e clones da Índia (D1, D2, D3, D4 e D5, azul), Indonésia (E2, cinza), Malásia (C1, azul-claro), Ilhas Salomão (A3, roxo), Costa do Marfim (G1 e G2, laranjas) e Honduras (H1, violeta).

\section{DISCUSSION}

The teak genotypes, divided into two groups, showed moderate levels of genetic diversity ( $\bar{A}=3.8$ -4.3 and $\left.H_{e}=0.37-0.61\right)$, lower than the literature data for teak ( $\bar{A}=2.1-7.7$ and $H_{e}=0.28-0.78$ ) (FOFANA et al., 2009), ( $\bar{A}=3.0-5.9$ and $\left.H_{e}=0.49-0.70\right)$ (VERHAEGEN et al., 2010), or when compared to other tree species as Eucalyptus globulus ( $\bar{A}=8.2$ - 9.7, and $H_{e}=0.77-0.83$ ) (MIMURA et al., 2009), Myracrodruon urundeuva $\left(\bar{A}=13.1-13.8\right.$, and $\left.H_{e}=0.68-0.75\right)$ (VIEGAS et al., 2011) and Carapa guianensis ( $\bar{A}=5.1$ - 5.7, and $H_{e}=0.57-0.58$ ) (RAPOSO et al., 2007), although higher when compared to other outcrossing trees, such as Vitellaria paradoxa $\left(\bar{A}=3.8-4.2\right.$, and $H_{e}=0.38$ - 0.44) (KELLY et al., 2004) and Grevillea macleayana ( $\bar{A}=3.2-4.2$, and $H_{e}=0.42-0.53$ ) (ENGLAND et al., 2002). The latter is a self-compatible species, whose mating system can vary among populations from random outcrossing to almost complete selfing (WHELAN et al., 2000).

We can elaborate three possible hypotheses to explain the lower values of $H_{e}$ when compared to Fofana et al. (2009) and Verhaegen et al. (2010): 1) the existence of founder effect, since Brazilian teak plantation results from a sample of few teak genotypes; 2) the possibility of high occurrence of endogamy and/or self-pollination; and 3) gain and loss of microsatellite loci.

The founder effect is defined as the establishment of a new population by few individuals who carry with them only a small fraction of the total genetic variation of the parental population (TEMPLETON, 1980). The implantation of teak in Cáceres results from a sample of few teak genotypes. Fofana et al. (2009) made their study in original forests of teak and Verhaegen et al. (2010) in genotypes from Africa and Indonesia, explaining the low number of alleles per loci in our study, ranging from 3 to 7 . The number of alleles per loci in Fofana et al. (2009) ranged from 3 to 19 and in Verhaegen et al. (2010) it ranged from 3 to 21 . Locus CIRAD1TeakG02 was not polymorphic in our study and therefore not informative for differentiation of genotypes. The same locus was the least polymorphic in Verhaegen et al. (2010) and Fofana et al. (2009). The highest polymorphic information content found in our work was observed for locus 3 (CIRAD1TeakH10) which was also the locus with the highest allelic richness in Fofana et al. (2009) and Verhaegen et al. (2010). 
Teak propagates mainly by cross-fertilization (KJAER et al., 1996; CHANGTRAGOON et al., 2000), reproductive system that enables high levels of genetic diversity within populations (HARTL, 2008). In our work, considering the genetic structure, we observed that most of the diversity found represents the diversity within groups (73\%, $\mathrm{P}<0.001)$, in agreement with data reported in the literature (HALL et al., 1994; KAGEYAMA et al., 2004; FOFANA et al., 2009). However, since we observed moderate levels of genetic diversity ( $\bar{A}=$ $3.8-4.3$ and $H_{e}=0.37-0.61$ ), high levels of endogamy or even self-pollination could be occurring within teak plantations in Brazil. According to Whelan et al. (2000), the patterns of pollinator visitation can explain some of this variation in reproduction; however, studies related to biology of propagation in teak plantations in Brazil are necessary to confirm this hypothesis.

According to Oliveira et al. (2006) and references therein, microsatellites have been widely used in a large number of studies that includes: construction of genetic maps, relationship with human genetic diseases, studies of population genetics, genotyping and paternity analysis. However, there is a concern about the lack of studies regarding the mutational dynamics of microsatellite regions since the mutation rate can vary from $10^{-2}$ to $10^{-6}$ nucleotides per locus per generation.

The origin of microsatellites could be explained by substitutions and insertions that duplicate adjacent sequences (ZHU et al., 2000). Mutations could occur in these regions because of errors during recombination, unequal crossing-over and failing during DNA reparation process which implicates in gain or loss of repeats, especially when unequal crossing-over occurs (OLIVEIRA et al., 2006). Therefore, we should not discard the possibility that mutation happens and could be implying in loss of repeats making the values of $H_{e}$ lower than those found in Fofana et al. (2009) and Verhaegen et al. (2010).

The genetic divergence found between Indonesia and Malaysia, which are geographically close, can be explained based on the work of Kertadikara and Prat (1995) that studied the isozyme variation of several provenances of teak and argued that the divergence found in populations of teak from Indonesia (more specifically from Java island) can be explained by the migration of teak possibly from eastern Myanmar and Thailand during the Pleistocene. Thus, due to reproductive isolation of teak on this island, the 20,000 years have been sufficient for the diversification of teak in the region. The genetic diversity found between the clones from Malaysia (C1 and C2) can be explained by the origin of each clone, since C1 was originated from the province of Perlis (northern Malaysia) and C2 from Kota Marudu (located on an island in Malaysia).

The cluster analysis, obtained using the Unweighed Neighbor-Joining algorithm, was consistent with the Bayesian analysis, separating the Cáceres genotypes from the other groups of genotypes, except for clone C2 (from Malaysia) and clone D6 (from India). Observing the Bayesian analysis and the Neighbor-Joining dendrogram, a considerable diversity between the genotypes from Cáceres and the other group of genotypes is observed, with few exceptions (27\% of total genetic divergence is explained by differences between the two groups). So, the following question was raised: could the genetic divergence between the two groups observed (Cáceres and other genotypes) be occurring due to reproductive isolation? The answer is probably not. The three possible hypothesis constructed previously also could explain the divergence, because teak has been introduced recently in Brazil and had little time for an evolutionary differentiation (i.e. 20,000 years of teak differentiation in Indonesia vs. almost 50 years of teak in Brazil). Therefore, considering the first hypothesis (founder effect), the new population (teak plantation in Cáceres) was started by a few members of the original population (represented by the other genotypes). The small population size means that the new population may have: a) reduced genetic variation from the original population (as we already elucidated using our data); and b) a non-random alleles sample of the original population (TEMPLETON, 1980). We can support the second consequence by the data on Table 3, which shows that the frequency of alleles in group 1 (majority Cáceres genotypes) is lower than group 2 which includes the genotypes from different origins.

Also, high levels of endogamy and/or selfpollination could be occurring since we noted that the average observed heterozygosity $\left(H_{o}\right)$ was much higher for group 2 (other genotypes) than group 1 (majority Cáceres genotypes). High levels of endogamy has already been observed in cross breeding species (MARTINS-CORDER et al., 1998) probably because of small size population and even self-pollination 
observed in allogamous trees depending of pollinators number (WHELAN et al., 2000). However, more studies of reproductive biology are required to confirm the last hypothesis in teak.

Gain or loss of repeats regions can occur because of mutations (OLIVEIRA et al., 2006). There is a possibility that the divergence between group 1 (majority Cáceres) and group 2 occurs because repeats appear or disappear for each group. However, further works regarding the mutation dynamic in teak are still necessary to confirm this hypothesis. The most divergent clones in this study can be used in crosses with genotypes from Cáceres, to test hybrids in order to explore the expression of heterosis and also to know the potential of a forest development composed by hybrid clones (COTERILL, 1997). The use of SSR markers to identify the most divergent varieties or inbred lines to aid in genetic improvement programs have been shown for other crops, such as maize (GETHI et al., 2002; VAN INGHELANDT et al., 2010). In our study, clones originated from India (except D6), Malaysia (except C2), Honduras, Indonesia, Solomon Islands and Ivory Coast were shown to be more divergent in the cluster analysis when compared to the Caceres materials, so it is possible to use any of these genotypes in controlled pollination for breeding programs as an attempt to achieve heterosis and more productivity. Clonal plantations derived from eucalyptus hybrids produced by controlled pollination have achieved productivity gains of around $100 \%$ over the plantations made with seeds, thus justifying its commercial exploitation (PARVEEN et al., 2010). Thus, this study will have essential importance to define the choices of teak genotypes that could be used in breeding programs aiming at the exploitation of teak heterosis in Brazil.

\section{CONCLUSIONS}

All the microsatellite markers used in this study, except primer CIRAD1TeakG02, can be useful to aid in the characterization of genotypes for protection of teak varieties in Brazil.

Most of the total genetic diversity is found within groups of genotypes (73\%), which is coherent to outcrossing reproductive system. However, when compared with teak literature, the average alleles per loci per group found in this work was lower than expected, suggesting that in Brazilian teak plantations there is a possible occurrence of founder effect, endogamy and/or self-pollination, and loss of alleles. We suggested new directions for further works in order to verify reproductive biology of teak in Brazil and studies of microsatellite mutation dynamics in teak.

Around $27 \%$ of total genetic diversity occurs between genotypes from Cáceres and those originated from India (except D6), Solomon Islands, Malaysia (except C2), Honduras, Indonesia and Ivory Coast. Possible candidates that we could recommend for teak breeding programs are A3 (from Solomon Island), C1 (from Perlis, Malaysia) and D1, D2 and D3 (from India) that showed higher genetic divergence when compared with Cáceres genotypes.

\section{ACKNOWLEDGMENTS}

The authors acknowledge the National Council of Scientific and Technological Development (CNPq) for supporting this work and Proteca and Floresteca companies for germplasm contribution. Also special thanks to Fernando Scognamiglio Torres, director of Proteca Forest Biotechnology, for the efforts and assistances that made this work possible.

\section{REFERENCES}

ALCÂNTARA, B. K. Caracterização da diversidade genética de teca (Tectonagrandis) de diferentes procedências usando marcadores microssatélites. 2009. 92f. Dissertação (Mestrado em Ciências) - Escola Superior de Agricultura “Luiz de Queiroz”, Universidade de São Paulo, Piracicaba, 2009.

ANGIOSPERM PHYLOGENY GROUP-APG. An update of the Angiosperm Phylogeny Group classification for the orders and families of flowering plants: APG III. Botanical Journal of the Linnean Society, v.161, n.2, p.105-121, 2009.

BASSAM B. J.; CAETANO-ANOLLES, G.; GRESSHOFF, P. M. Fast and sensitive silver staining of DNA in polyacrylamide gels. Analytical Biochemistry, v.196, n.1, p.80-83, 1991.

BORGES, A. et al. CTAB methods for DNA extraction of sweetpotato for microsatellite analysis. Scientia Agricola, v.66, n.4, p.529-534, 2009.

Revista Árvore, Viçosa-MG, v.37, n.4, p.747-758, 2013 
BOTSTEIN, D. et al. Construction of genetic linkage map in man using restriction fragment length polymorphisms. American Journal of Human Genetics, v.32, n.3, p.314-331, 1980.

CHANGTRAGOON, S.; SZMIDT, A. E. Genetic diversity of teak (TectonagrandisL.f.) in Thailand revealed by Random Amplified Polymorphic DNA (RAPD) markers. In: IUFRO WORKING PARTY 2.08.01 TROPICAL SPECIES BREEDING AND GENETIC RESOURCES: FOREST GENETICS FOR THE NEXT MILLENNIUM, 2000,Durban. Proceedings... Durban: IUFRO, 2001. 83p.

COTERILL, P. P. Nucleous breeding: Is it ok for Pinus and Eucalyptus? Oxford: Forestry Institute, 1997. 284p.

ENGLAND, P. R.; USHER, A. V.; WHELAN, R. J. Microsatellite diversity and genetic structure of fragmented populations of the rare, fire-dependent shrub Grevilleamacleayana. Molecular Ecology, v.11, n.6, p.967-977, 2002.

EVANNO, G.; REGNAUT, S.; GOUDET, J. Detecting the number of clusters of individuals using the software STRUCTURE: a simulation study. Molecular Ecology, v.14, n.8, p.26112620, 2005.

EXCOFFIER, L.; LAVAL, G.; SCHNEIDER, S. Arlequin ver. 3.11: An Integrated Software for Population Genetics Data Analysis (Software). Institute of Ecology and Evolution, University of Bern, Baltzerstrasse, Switzerland, 2006. Available at: http://cmpg.unibe.ch/software/ arlequin3/. Accessed in Oct. 14, 2008.

FIGUEIREDO, E. O. Reflorestamento com teca (Tectonagrandis L.F.) no estado do Acre. Embrapa Acre:2001.(Documento, 65) Available at: http://www.cpafac.embrapa.br/pdf/ doc65.pdf. Accessed in Nov. 14, 2008.

FOFANA, I. J. et al. Diversity and genetic structure of teak (Tectonagrandis L. f.) in its natural range using DNA microsatellite markers. New Forests, v.37, n.2, p.175-195, 2009.

GANGOPADHYAY, D. et al. Micropropagation of Tectonagrandis: assessment of genetic fidelity. Biologia Plantarum, v.46, n.3, p.459-461, 2003.
GETHI, J. G. et al. SSR variation in important U.S. maize inbred lines.Crop Science, v.42, n.3, p.951-957, 2002.

GOUDET, J.FSTAT (Version 1.2): a computer program to calculate F statistics, 1995. Available at: http://www2.unil.ch/popgen/ softwares/fstat.htm. Accessed in Aug. 20, 2009.

GRAUDAL, L. et al. Conservation of genetic resources of teak (Tectonagrandis) in Thailand. In: DFSC SERIES OF TECHNICAL NOTES. Humlebaek: Danida Forest Seed Centre, 1999. 38p.

HALL, P.; CHASE, M. R.; BAWA, K. Low genetic variation but high population differentiation a common tropical forest tree species. ConservationBiology, v. 8, n.2, p.471-482, 1994.

HARTL, D. L. Princípios de genética de população. RibeirãoPreto: FUNPEC, 2008. 217p.

HEDEGART, T.; EIGAARD, J.Chromosome number of Teak (TectonagrandisL. f.). Hørsholm: The Arboretum, 1965. 115p.

KAGEYAMA, P. Y. et al. Genetic and ecological aspects of nonwood forest product exploitation in two western Amazonian settlements. In: CHALLENGES IN MANAGING FOREST GENETIC RESOURCE FOR LIVELIHOODS: EXAMPLES FROM ARGENTINAAND BRAZIL. Roma: IPGRI, 2004. p.149-217.

KELLY B. A.; HARDY O. J.; BOUVET J. M. Temporal and spatial genetic structure in Vitellariaparadoxa (shea tree) in an agroforestry system in southern Mali. Molecular Ecology, v.13, p.1231-1240, 2004.

KERTADIKARA, A. W. S.; PRAT, D. Isozyme variation among teak (TectonagrandisL.f.) provenances. Theoretical and Applied Genetics, v.90, p.803-810, 1995.

KJAER, E. D.; SIEGISMUND, H. R.; SUANGTHO, $\mathrm{V}$. A multivariate study on genetic variation in teak (Tectonagrandis). Silvae Genetics, v.45, n.5-6, p.361-368, 1996. 
KOLLERT, W.; CHERUBINI, L. Teak resources and market assessment 2010. FAO Planted Forests and Trees Working Paper FP/47/E. Rome. 2012. Available at: http:// www.fao.org/forestry/plantedforests/ 67508@170537/en/. Accessed in June 18, 2013.

KOLLERT, W.; CHERUBINI, L. Teak resources and market assessment 2010. FAO Planted Forests and Trees Working Paper FP/47/E, Rome. 2012. Available at: http:// www.fao.org/forestry/plantedforests/ 67508@170537/en/. Accessed in June 18, 2013.

KRISHNAPILLAY, B. Silviculture and management of teak plantations. Unasylva, v.51, n.201, p.14-21, 2000.

LEWIS, P. O.; ZAYKIN, D. Genetic data analysis: computer program for the analysis of allelic data (software). Version 1.1., 2001. Available at: <http:// hydrodictyon.eeb.uconn.edu/people/plewis/ software.php>. Accessed in Aug. 20, 2009.

MARTINS-CORDER, M. P.et al.Genetic diversity of three size classes of seeds of Eucalyptus globulus. Silvae Genetica, v.47, n.1, p. 6-14, 1998.

MATRICARDI, W. A. T. Efeito dos fatores do solo sobre o desenvolvimento da teca (Tectonagrandis L.F.) cultivada em Grande Cárceres - Mato Grosso. 1989. 135f. Dissertação (Mestrado em Ciências Florestais) - Escola Superior de Agricultura “Luiz de Queiroz”, Universidade de São Paulo, Piracicaba, 1989.

MILLER, M. P.Tools for population genetic analyses (TFPGA) 1.3: a windows program for the analysis of allozyme and molecular population genetic data, 1997. Available at: <http:// www.public.asu.edu>. Accessed in Mar. 5, 2007.

MIMURA, M.; et al. Comparison of contemporary mating patterns in continuous and fragmented Eucalyptus globulus native forests. Molecular Ecology, v.18, p.41804192, 2009.
NEI, M. Analysis of gene diversity in subdivided populations. Proceedings of the National Academy of Science of the United States of America, v.70, n.12, p.3321-3323, 1973.

NEWTON, A. C. et al. Domestication of mahoganies. In: TROPICAL TREES: THE POTENTIAL FOR DOMESTICATION AND THE REBUILDING OF FOREST RESOURCES. London: HMSO, 1994. p.256-266.

OLIVEIRA, E. J. et al. Origin, evolution and genome distribution of microsatellites. Genetics and Molecular Biology, v. 29, n. 2, pp. 294-307, 2006.

PARVEEN, A. K.; SHARMA, V. K.; GINWAL, H. S.Sustained hybrid vigor in F1 hybrids of Eucalyptus torellianaF.v.Muell x E. citriodoraHook. World Applied Sciences Journal,v.11, p.830-834, 2010.

PERRIER, X.; FLORI, A.; BONNOT, F. Data analysis methods. In: GENETIC DIVERSITY OF CULTIVATED TROPICAL PLANTS. Montpellier: Science Publishers, 2003. p.43-76.

PRITCHARD, J. K.; STEPHENS, M.; DONNELLY, P. Inference of population structure using multilocus genotype data. Genetics, v.55, p.945-959, 2000.

RAPOSO, A. et al. Diversidade genética de populações de andiroba no Baixo Acre.

PesquisaAgropecuária Brasileira, v.42, n.9, p.1291-1298, 2007.

RONDON NETO, R. M.; MACEDO, R. L. G.; TSUKAMOTO FILHO, A. A. Formação de povoamentos florestais com TectonagrandisL.f. (Teca). Lavras: Universidade Federal de Lavras, 1998. 29p. (Boletim Técnico. Série Extensão, 33).

SHRESTHA, M.K.; VOLKAERT, H.; STRAETEN, D.V.D. Assessment of genetic diversity in Tectonagrandis using amplified fragment length polymorphism markers. Canadian Journal Forest Research, v.35, p.1017-1022, 2005.

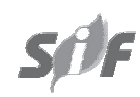

Revista Árvore, Viçosa-MG, v.37, n.4, p.747-758, 2013 
TEMPLETON, A. R. The theory of speciation via the founder principle. Genetics, v.94, p.1011-1038, 1980.

TSUKAMOTO FILHO, A.A. et al. Análise econômica de um plantio de teca submetido a desbastes.Revista Árvore, v.27, n.4, p.487-494, 2003.

UGALDE, L.; PÉREZ, O.Mean annual volume increment of selected industrial forest. FAO, Working paper FP/1, FAO, Rome, 2001. Available at: <http://ftp.fao.org/ docrep/fao/006/ac121e/ac121e00.pdf $>$. Accessed in Aug. 22, 2007.

van INGHELANDT, D. et al. Population structure and genetic diversity in a commercial maize breeding program assessed with SSR and SNP markers.Theoretical and Applied

Genetics, v.120, n.7, p.1289-1299, 2010.

VERHAEGEN, D. et al. Development and characterization of microsatellite markers in Tectonagrandis (Linn. f). Molecular Ecology Notes, v.5, n.4, p.945-947, 2005.

VERHAEGEN, D. et al.What is the genetic origin of teak (Tectonagrandis L.) introduced in Africa and in Indonesia?Tree Genetics \& Genomes, v.6, n.5, p.717-733, 2010.
VIEGAS, M. P. et al. Diversidade genética e tamanho efetivo de duas populações de Myracrodruonurundeuva Fr. All., sob conservação ex situ.RevistaÁrvore, v.35, n.4, p.769-779, 2011.

WATANABE, A.; WIDYATMOKO, A.

Discrimination of teak (Tectonagrandis) plus trees using selected Random Amplified Polymorphic DNA (RAPD) markers. Journal of Tropical Forest Science, v.16, n.1, p.17-24, 2004.

WHELAN, R. J. et al. Ecology and genetics of Grevillea (Proteaceae): implications for conservation of fragmented populations. Genetics, Demography and Viability of Fragmented Populations. Cambridge: Cambridge University Press, 2000. p.253-270. Cambridge Books Online. Available at: http://dx.doi.org/10.1017/ CBO9780511623448.019. Accessed in June 14, 2013.

WRIGHT, S. Evolution and the genetics of populations. Variability within and among natural populations. Chicago: University of Chicago Press, 1978.

ZHU, Y.; ESTRASSMANN, J. E.; QUELLER, D. C. Insertions, substitutions, and the origin of microsatellites. Genetical Research, v. 76, n. 3, p. 227-236, 2000. 